ISSN: 2600-5859

WWW.concienciadigital.org

Vol. 3, N¹.1, p. 408-426, febrero, 2020

\title{
Juegos de lenguaje para mejorar la habilidad del habla en estudiantes de los primeros niveles del idioma inglés en la universidad
}

\section{Language games to enhance the speaking skill on beginner English language learners at University}

Jazmina Ivonne Mena Mayorga. ${ }^{1}$, Angela Cecibel Moreno Novillo. ${ }^{2}$, Carmen Cecilia Mejía Calle. ${ }^{3} \&$ Juan Carlos Silva Valencia. ${ }^{4}$

Recibido:01-12-2019 / Revisado: 02-01-2020 /Aceptado: 18-01-2020/ Publicado: 07-02-2020

\begin{abstract}
DOI: $\underline{\text { https://doi.org/10.33262/concienciadigital.v3i1.1.1157 }}$
\end{abstract}

This research aimed to discover if language games used as a teaching strategy improve the ability to speak English. The target population was fifty-two first level students at a university in Ecuador. Twenty-six students were part of the experimental group and the remaining twenty-six students were part of the control group. A previous test was applied for both groups to know their level of conversation. The results showed that both groups had a very basic level of speech. Consequently, language games were applied to students in the experimental group as a strategy to improve their ability to speak English. After this process, the students of both groups took a subsequent test to see if the games used during the classes made any difference with respect to the ability to speak. The findings indicated that students belonging to the experimental group obtained a higher average in the subsequent test compared to the average obtained by the control group. Therefore, it is important to consider that the averages of the experimental group exceeded the averages of the control group. Based on these findings, games as a teaching strategy improved the ability to speak English in the first level students of the university.

Keywords: Language games, speaking skill, teaching strategy, beginner English language learners.

\footnotetext{
${ }^{1}$ Escuela Superior Politécnica de Chimborazo, Faculty of Mechanics. Riobamba, Ecuador. jazmina.mena@espoch.edu.ec

${ }^{2}$ Escuela Superior Politécnica de Chimborazo, Faculty of Mechanics. Riobamba, Ecuador. angela.moreno@espoch.edu.ec

${ }^{3}$ Escuela Superior Politécnica de Chimborazo, Language Center. Riobamba, Ecuador. cmejia@espoch.edu.ec

${ }^{4}$ Universidad Técnica de Ambato, Language Center. Ambato, Ecuador. jc.silva@uta.edu.ec
} 


\section{Resumen}

Esta investigación tuvo como objetivo descubrir si los juegos de lenguaje utilizados como estrategia de enseñanza mejoran la habilidad de hablar inglés. La población objetivo era cincuenta y dos estudiantes de los primeros niveles en una universidad en Ecuador. Veintiséis estudiantes fueron parte del grupo experimental y los veintiséis estudiantes restantes fueron parte del grupo de control. Se aplicó una prueba previa para ambos grupos para conocer su nivel de conversación. Los resultados demostraron que ambos grupos tenían un nivel de habla muy básico. En consecuencia, los juegos de lenguaje se aplicaron a los estudiantes en el grupo experimental como una estrategia para mejorar su habilidad de hablar inglés. Después de este proceso, los estudiantes de ambos grupos tomaron una prueba posterior para ver si los juegos utilizados durante las clases hicieron alguna diferencia con respecto a la habilidad de hablar. Los hallazgos indicaron que los estudiantes que pertenecían al grupo experimental obtuvieron un promedio más alto en la prueba posterior en comparación con el promedio obtenido por el grupo de control. Por lo tanto, es importante considerar que los promedios del grupo experimental superaron a los promedios del grupo de control. En base a estos hallazgos, los juegos como estrategia de enseñanza mejoraron la habilidad de hablar inglés en los estudiantes de primer nivel de la universidad.

Palabras claves: Juegos de lenguaje, habilidad de hablar inglés, estrategia de enseñanza.

\section{Introduction}

Teaching English as a foreign language in Ecuador is a challenging job for the only opportunity for learners to practice their speaking skill is inside the classroom. This fact encourages teachers to be empowered with the necessary teaching tools to enhance this skill.

Ecuadorian people start learning English since elementary school until they go to university. This statement absolutely confirms that learners have a long time of exposure to the language. However, they are not able to communicate in English. An institution uncharged of researching regarding the English language in Ecuador, claimed that it has a low English level. Education First (2017) declares that Ecuador got the fifty-five place among eighty countries that were evaluated by the English Proficiency Index. They also added that the average Ecuadorian students obtained in this test was forty- nine over one hundred. The low English level Ecuadorians 
have is a vast concern for the authorities who are in charge of language policy and planning. As a consequence, they determined to reinforce the English level teachers and professors have in the different educational institutions around the country. This can be found in the law according to Acerbo Ministerial N. 41-13 from the Republic del Ecuador, Ministry of Education (2013). Thus, it was mandatory for all Ecuadorian English educators to get a B2 certificate as established in the Common European Framework of Reference (CEFR). Unfortunately, this law has not solved the low English level in this country completely.

The problem is still evidenced when most higher education students do not speak English. This might be happening due to different factors such as teaching methods, lack of intrinsic and extrinsic motivation or low future expectations. Firstly, professors play such an important role in this process of learning a language that if they do not look for the right strategies to make the classes meaningful and entertaining, students lose interest in learning the language. (Calle, Calle, Argudo, Moscoso, Smith, Cabrera (2012) cited in Mena (2018) asserted that students have limited use of the English language because of the lack of effective teaching strategies. This ratifies that the problem is not only the English proficiency level a professor could have, it has to do with the way the teaching process is carried out. Therefore, it is clear that there are problems in the teachinglearning process that must be tackled with immediate action. On the other hand, speaking is a productive skill which necessarily needs to be practiced in class. Reading and writing could be sent as homework, but there is no other opportunity for students to talk that it is inside the class. For that reason, professors should be able to apply different strategies to make students talk and be able to communicate.

The fact that English professors are not aware of language games to develop the speaking skill causes boring classes and bored students. If there are not dynamic activities learners get bored easily and the learning process becomes exhausting for teachers and students. Due to short attention span, it is necessary to include a lot of activities for the class to be active and productive. Most students like to play games in class because they make them smile and have fun. In addition, some games required students to move around, talk to each other and get involved in their own learning. For all of these reasons, it is advantageous to have knowledge of games that 
can be performed at the beginning of the class, during the class if students are bored and at the end of the class as a wrap-up.

A second fact is the belief that games are just games and do not develop any skill. This reduces the opportunities for students to speak English. Professors think games are only applicable to kindergarten or elementary school students, but not for university students. But they are not aware that adults and young adults enjoy games as part of the lesson too. In every class, there are shy students who do not like to speak because they are afraid of making mistakes in front of their classmates. Game strategy takes mistakes as part of the learning process, so shy learners do not feel afraid of making mistakes.

\section{Theoretical Framework}

There are different strategies an educator might select to develop listening, speaking, reading and writing. Language games are an alternative for English teachers to have meaningful and enjoyable lesson plans, also at the same time those give students the opportunity to use the target language without being aware of grammar. According to Hadfield (1996) games are planned activities with instructions, an aim and a component of fun. Also, games are activities in which learners play and there is interaction among them. Undoubtedly, games are linked to language teaching and learning. Students are relaxed while playing games and learn different grammar patterns.

Similarly, Gaudart (1999) cited in Mena (2018) claimed that games are one of the most effective strategies for professors to apply in their classes. He stated that games permit students to practice previous, current and new structures of the language. He pointed out that games provide non-threatening settings. As a result, games are a great teaching strategy that professors can add to their lesson plans. This strategy allows students to practice old knowledge as well as building new knowledge. The most important fact is that students do not feel anxious when playing games since they are fun and there is not any kind of punishment because the main purpose of using games in the English language classroom is encouraging learners to use the target language.

In the same regard, Mahmoud and Tanni (2014) cited in Mena (2018) expressed that adding games in the lesson plan could raise interest and strengthen previous knowledge. They also said 
that games are an encouraging, communicative and cooperative strategy for teaching. Furthermore, games enhance team cooperation and allow students to participate actively.

Motivation and learning are extremely connected in educational settings. In fact, Urrutia and Vega (2010) stated that games are considered the best motivation to help students speak in an appropriate atmosphere; which means that if there is no motivation at all for learning English, students might fail. Teachers could help students to reinforce both intrinsic and extrinsic motivation. The first one will automatically grow by the strategies the educator uses in class. In this case, language games will definitely make students like learning English. Students will be motivated to come to the English class every day. In addition, games avoid boredom since they can be used at the beginning, during the class but also at the end of the class as a wrap- up. In this regard, Sevy-Biloon (2017) cited in Mena (2018) pointed out that games can be used to as teaching method to reinforce language aspects in the language learning process while simultaneously fostering language skills.

Likewise, language games are communicative activities that provide students real context situations. For instance, a word cannot be learned by itself, it needs a setting. If this setting is a real-life situation learning occurs unconsciously. Deesri (2002) argued that learners do not make a lot of effort thinking about what to say when using the target language since games provoke spontaneous and real circumstances. Thereby, English learners can use the language outside the class. Certainly, that is the aim of learning a foreign language that students are able to communicate. If educators planned on games for teaching, they will definitely provide genuine context for students to produce English. However, it is difficult for a teacher to find strategies that motivate students and at the same time improve listening, speaking, reading and writing. Arikan and Yolagelddili (2011) cited in Mena (2018) stated that games develop and stimulate the four skills. They also claimed that games offer students the opportunity to use grammatical structures by performing them in a communicative manner. Furthermore, games can combine two or more skills in one game. For instance, when students play the game called running dictation, they put into practice three skills reading, writing and speaking. Then using games in the class will positively affect one or more of the four skills. If teachers see games as a serious strategy for teaching English and planned on them. Students will improve their skills without memorization of grammar patterns or tedious grammatical forms. Language games are a good and easy alternative 
for teachers and students to enjoy. That is why selecting games as a strategy to teach English supports and benefits learners.

Everybody likes playing games because it is fun. Games make people smile as well as make students smile in the educational field. They keep learners calm and relaxed in order to learn. When there is a tense environment, there is not learning. Fisher and Schultz (1988) cited in Mena (2018) declared that stress levels are an obstacle for students to pay attention. Traditional strategies are a waste of time, stimulate stress and they also diminish motivation. He claimed that when students play a game, they forget they are in class. In other words, games reduce stress students face when learning English.

Considering that it is hard for shy students to develop the speaking skill, educators should always look for strategies to allow them to speak. Strategies that make them speak without being afraid of making mistakes. Games are al alternative for these students because playing games allow students to make mistakes. So, they feel free to communicate in English. Dewi, Kultsum \& Armandi (2017) cited in Mena (2018) described games as a strategy which allows students to trust in themselves when speaking. They also report that learning with games generates great and pleasant situations. Learners can actively participate playing games and nurture their selfconfidence.

It is also important to point out that almost all people who learn English want to be able to communicate. To achieve this desire, it is important to enhance the teaching process. That is why communicative language teaching appears as a good alternative to help teachers create communicative environments in class. Harmer (2007) cited in Mena (2018) defined Communicative Language Teaching (CLT) as a group of principles regarding "what to teach" and "how to teach". He claimed that the first one refers to language functions and the second one refers to two aspects, language exposure and opportunities to use the language. Finally, he mentions that the activities suggested by CLT require real communication where accuracy is not as important as succeed in the communicative task.

The kinds of activities suggested in CLT involve new roles for the teachers and learners in the classroom. According to Larsen-Freeman (2004) cited in Mena (2018) the role of the professors is to provide students with opportunities to use the target language through setting situations that 
ISSN: 2600-5859

provoke communication. In other words, to plan on activities that make them communicate with each other or in groups. The author also said that the chief role of the learners is to be "communicators" and actively participate in trying to make themselves understood and understand others. The author also pointed out that students should use the target language even if they are beginners. Another point the author highlights is the student-centered class where the students are responsible managers of their own learning. Both roles are crucial, especially the role of the teacher since he/she guides and leads the students. Therefore, if the teacher does well his/her role, it will be easier for students to carry out their role. For example, if teachers bring communicative activities that are well planned, and they give clear instructions, students will automatically fulfill their role.

In this respect, Murphy and Sashi (2017) cited in Mena (2018) explained that communication is possible when the message is conveyed suitably. For this reason, these authors talked about modes of communication which have been examined based on their synchronicity, speed of transmission, and ability to transmit information. They also mentioned that when a person uses an accurate mode of communication, effective communication takes place. A table shows three modes of communication.

\section{Table 1}

\section{Framework for the communication modes}

\begin{tabular}{lll}
\hline \multicolumn{1}{c}{ Interpersonal } & \multicolumn{1}{c}{ Interpretative } & Presentational \\
\hline $\begin{array}{l}\text { Direct oral communication } \\
\text { between individuals who are }\end{array}$ & Receptive communication & Productive communication \\
in personal contact. & of oral or written messages & using oral or written language \\
Direct written communication & Meditated communication via print & Spoken or written communication \\
between individuals who came & and non-print materials. & for people (an audience) with \\
into personal contact. & & whom there is no immediate \\
& & personal contact. \\
Productive abilities: speaking, & Primarily receptive abilities: & Primarily productive abilities: \\
Writing & listening, reading, viewing & speaking, writing.
\end{tabular}

Source: Murphy, Sashi (2017)

Developed by: The authors 
Language is a complex phenomenon which goes beyond learning grammar only. Tudor (2001) cited in Mena (2018) explained that language is considered a social action that is why the communicative language teaching (CLT) pointed out that language learners need to use the language according to the context they are being faced at any time. He also added that learners should be able to do something in or with this language, in other words, to use the language in different contexts. Tudor also pointed out that there is a goal behind a person who is learning English, for instance, performing professional tasks such as answering the phone or providing information to customers, traveling abroad, studying abroad or doing business.

Having a clear idea of why professors are teaching specific parts of language in a course, makes a great difference because a professor who is teaching English to someone who requires it for academic purposes cannot be teaching business vocabulary. So, the objective of learning English should also be considered by the professor so he/she matches students' needs. Tudor provided an example of this as follows "a business person who needs to improve his/her English needs functions such as greeting, introducing people, keeping a conversation going, etc." This would be called needs analysis that goes along with English for specific purposes.

The demand for an appropriate teaching methodology is as stronger as ever. That is why CLT makes it clear that teaching grammar and vocabulary is not enough for communication to happen. It is necessary to empower students' skills to communicate through activities that make them have the desire to communicate. For example, role plays, games, writing emails, etc. These activities will help students to concentrate on the content rather than any particular language form. This makes absolute sense for teachers whose job is teaching their students more than a formula to teach grammar.

Concerning one of the productive skills, specifically speaking, Yong (2013) cited in Mena (2018) defined this as follows "Speaking is the productive skill in the oral mode. It, like the other skills, is more complicated than it seems at first and involves more than just pronouncing words. It involves some other sub-kills such as pronunciation, fluency, grammar, vocabulary, and comprehension." Speaking is the skill where learners show the use of language in order to communicate. The author also highlights that the speaking skill does not stand alone it needs some other sub-skills. Ur (1997) cited in Mena (2018) declared that the definition of pronunciation 
ISSN: 2600-5859

WWW.concienciadigital.org

Vol. 3, $\mathrm{N}^{\circ} 1.1$, p. 408-426, febrero, 2020

embraces the sounds of the language (phonology), stress and rhythm and intonation. It also shows a relationship with spelling.

In this sense, Ur (1997) also claimed that "the term phonetic is used to refer to transcripts of the sounds of all human languages which make distinctions between sounds that may not be distinguished in a given language system."

\section{Table 2}

\section{Differences between written and spoken grammar}

\begin{tabular}{ll}
\hline Written grammar & Spoken grammar \\
\hline Clauses are often embedded (subordination) & Clauses are usually added (co-ordination) \\
Reported speech favored & Direct speech favored \\
Precision favored & Vagueness tolerated \\
Little ellipsis & A lot of ellipsis \\
No question tags & Many question tags \\
No performance effects & Performance effects, including \\
& hesitations, repeats, false starts, \\
& incompletion, syntactic blends
\end{tabular}

Source: How to teach speaking-Scott Thornbury (2009)

Developed by: The authors

Speaking is considered one of the most challenging skills in comparison with the other three macro skills. However, it is highly necessary to achieve it in order to have effective communication. Zaremba (2006) cited in Mena (2018) claimed that the speaking skill plays an important role in communication, in fact, having a good speaking skill is placed ahead of any other skill when hiring people for a job. Consequently, practicing speaking in the class should be one of the main priorities for a professor. Providing students with lots of opportunities to speak English is the best way to enhance this skill, for students who study English as a foreign language (EFL) the classroom is the only place where they can practice the language.

It can be said that language is a system of communication that helps people to express ideas, feelings and experiences. Language is a wonderful tool living creatures have in order to make communication possible. 


\section{Methodology}

This study was conducted using a quantitative approach. Firstly, this research formulated a delimitation of the problem. This means the setting was specific and limited at the beginning of the study. Secondly, the hypothesis was previously established. Thus, this investigation had a hypothesis before the data collection. Finally, the data collection was measurable, as well as the results were analyzed through statistics.

This research was led by the quasi-experimental design of investigation. It was carried out in two groups, the control and the experimental. Both groups had similar features. One group followed the intervention plan and the other one did not. At the end of the intervention plan, the results were compared and analyzed. This research is also descriptive because it analyzed each variable independently through the literature presented in the theoretical framework. In addition, the two variables were detected by some other researchers so there is data in which this study was based on. It additionally measured the dependent variable through evaluation tools. According to Hernández, Fernández and Baptista (2016) cited in Mena (2018), the purpose of the descriptive level is measuring the two variables individually. Another reason why this research started with this level of research is that the results of the pre and post-tests were compared and analyzed. Furthermore, this research is correlational since it determined if the independent variable, language games, influences the dependent variable, speaking skill. This level of study allowed the researcher to know if there is any relation between the two variables.

Fifty- two (52) students were the population of this study. They were students of the first levels, classes "C" and "D" at a university in Ecuador. Being class "C" the experimental group, and class " $\mathrm{D}$ " the control group. There were twenty-six students (26) in the experimental group as well as twenty-six (26) students in the control group. Both groups, the experimental group and the control group took the pre-test and post-test, nonetheless only the experimental group experienced learning to speak English using language games presented in the intervention plan. Finally, the researcher used research instruments such as the observation, questionnaires, pre-test and posttest, speaking rubrics and recording of the participants' speaking performance.

Hernandez et al. (2016) claimed that descriptive statistics as its name points out describes numbers, scores and all kind of data. Therefore, data was collected by giving students a pre-test 
ISSN: 2600-5859

and a post-test, which was classified, organized and codified. This helped to compare the average obtained in the post-tests in both groups. Also, each criterion from the rubric in the pre-test and post-test was analyzed and represented through bar graphics. Tables were also used to represent the scores gotten. Moreover, a very short questionnaire is applied after taking the post-test for the learners in the experimental group. This information was organized and analyzed using tables and pie charts in order to represent quantities and have a better understanding of the data collected.

Table 3

Pre-test control group

\begin{tabular}{ccccccc}
\hline Student & Comprehension & Fluency & Grammar & Vocabulary & Pronunciation & Total \\
\hline 1 & 2 & 1 & 2 & 1 & 1 & 7 \\
2 & 2 & 1 & 1 & 1 & 1 & 6 \\
3 & 2 & 2 & 1 & 1 & 2 & 8 \\
4 & 2 & 1 & 1 & 1 & 1 & 6 \\
5 & 2 & 1 & 1 & 1 & 1 & 6 \\
6 & 2 & 1 & 2 & 1 & 2 & 8 \\
7 & 2 & 1 & 1 & 1 & 1 & 6 \\
8 & 3 & 3 & 3 & 3 & 3 & 15 \\
9 & 3 & 3 & 2 & 3 & 3 & 14 \\
10 & 2 & 2 & 1 & 1 & 1 & 7 \\
11 & 3 & 3 & 3 & 3 & 3 & 15 \\
12 & 3 & 3 & 2 & 2 & 2 & 12 \\
13 & 1 & 1 & 1 & 1 & 1 & 5 \\
14 & 2 & 2 & 1 & 1 & 1 & 7 \\
15 & 1 & 1 & 2 & 1 & 1 & 6 \\
16 & 2 & 2 & 1 & 1 & 2 & 8 \\
17 & 2 & 2 & 1 & 3 & 2 & 10 \\
18 & 2 & 1 & 2 & 2 & 2 & 9 \\
19 & 3 & 3 & 2 & 3 & 3 & 14 \\
20 & 2 & 2 & 2 & 2 & 2 & 10 \\
21 & 3 & 3 & 2 & 2 & 3 & 13 \\
22 & 3 & 2 & 2 & 3 & 3 & 13 \\
23 & 3 & 2 & 2 & 2 & 2 & 11 \\
24 & 3 & 3 & 3 & 3 & 2 & 14 \\
25 & 2 & 3 & 2 & 2 & 2 & 11 \\
26 & 2 & 2 & 2 & 2 & 10 \\
$\mathbf{X}$ & $\mathbf{2 , 2 7}$ & $\mathbf{1 , 9 6}$ & $\mathbf{1 , 7 3}$ & $\mathbf{1 , 8 1}$ & $\mathbf{1 , 8 8}$ & $\mathbf{9 , 6 5}$ \\
\hline $\mathbf{2 0}$ & & & & & &
\end{tabular}

Results

Note: The media or average of the control group regarding the pretest is 9, 65 over 25.

Source: Pre-test control group

Developed by: The authors 
Table 4

Pretest experimental group

\begin{tabular}{|c|c|c|c|c|c|c|}
\hline Student & Comprehension & Fluency & Grammar & Vocabulary & Pronunciation & Total \\
\hline 1 & 3 & 2 & 3 & 2 & 3 & 13 \\
\hline 2 & 3 & 3 & 2 & 3 & 3 & 14 \\
\hline 3 & 1 & 2 & 1 & 1 & 2 & 7 \\
\hline 4 & 1 & 2 & 1 & 1 & 1 & 6 \\
\hline 5 & 3 & 3 & 2 & 1 & 2 & 11 \\
\hline 6 & 2 & 1 & 2 & 1 & 1 & 7 \\
\hline 7 & 1 & 2 & 1 & 1 & 2 & 7 \\
\hline 8 & 1 & 2 & 2 & 1 & 1 & 7 \\
\hline 9 & 3 & 3 & 2 & 2 & 3 & 13 \\
\hline 10 & 3 & 3 & 3 & 2 & 3 & 14 \\
\hline 11 & 3 & 2 & 2 & 2 & 2 & 11 \\
\hline 12 & 2 & 2 & 2 & 1 & 1 & 8 \\
\hline 13 & 2 & 1 & 1 & 2 & 2 & 8 \\
\hline 14 & 2 & 1 & 1 & 1 & 1 & 6 \\
\hline 15 & 2 & 3 & 3 & 3 & 3 & 14 \\
\hline 16 & 2 & 2 & 2 & 1 & 1 & 8 \\
\hline 17 & 1 & 1 & 1 & 1 & 1 & 5 \\
\hline 18 & 2 & 2 & 1 & 1 & 2 & 8 \\
\hline 19 & 3 & 1 & 1 & 1 & 1 & 7 \\
\hline 20 & 3 & 2 & 3 & 2 & 2 & 12 \\
\hline 21 & 2 & 2 & 2 & 2 & 2 & 10 \\
\hline 22 & 3 & 2 & 2 & 2 & 2 & 11 \\
\hline 23 & 2 & 2 & 2 & 2 & 2 & 10 \\
\hline 24 & 3 & 3 & 3 & 4 & 4 & 17 \\
\hline 25 & 2 & 2 & 2 & 2 & 2 & 10 \\
\hline 26 & 2 & 1 & 1 & 1 & 1 & 6 \\
\hline $\mathbf{X}$ & 2,19 & 2 & $\mathbf{1 , 8 5}$ & 1,65 & $\mathbf{1 , 9 2}$ & 9,62 \\
\hline
\end{tabular}

Note: The media or average of the experimental group regarding the pretest is 9,62 over 25 .

Source: pre-test experimental group

Developed by: The authors 
ISSN: 2600-5859

wWw.concienciadigital.org

Vol. 3, $\mathrm{N}^{\circ} 1.1$, p. 408-426, febrero, 2020

Table 5

Post-test control group

\begin{tabular}{|c|c|c|c|c|c|c|}
\hline Student & Comprehension & Fluency & Grammar & Vocabulary & Pronunciation & Total \\
\hline 1 & 3 & 3 & 2 & 3 & 3 & 14 \\
\hline 2 & 2 & 2 & 2 & 2 & 2 & 10 \\
\hline 3 & 3 & 3 & 3 & 3 & 3 & 15 \\
\hline 4 & 3 & 3 & 3 & 3 & 3 & 15 \\
\hline 5 & 4 & 4 & 3 & 3 & 3 & 17 \\
\hline 6 & 3 & 3 & 2 & 2 & 2 & 12 \\
\hline 7 & 3 & 3 & 2 & 3 & 3 & 14 \\
\hline 8 & 4 & 3 & 3 & 3 & 3 & 16 \\
\hline 9 & 5 & 4 & 3 & 3 & 3 & 18 \\
\hline 10 & 3 & 3 & 3 & 3 & 3 & 15 \\
\hline 11 & 3 & 3 & 3 & 4 & 4 & 17 \\
\hline 12 & 3 & 3 & 3 & 3 & 3 & 15 \\
\hline 13 & 3 & 2 & 3 & 2 & 2 & 12 \\
\hline 14 & 4 & 3 & 4 & 4 & 5 & 20 \\
\hline 15 & 3 & 3 & 2 & 2 & 2 & 12 \\
\hline 16 & 2 & 1 & 2 & 1 & 1 & 7 \\
\hline 17 & 3 & 3 & 3 & 2 & 2 & 13 \\
\hline 18 & 3 & 3 & 3 & 3 & 3 & 15 \\
\hline 19 & 3 & 4 & 3 & 3 & 3 & 16 \\
\hline 20 & 5 & 5 & 5 & 5 & 5 & 25 \\
\hline 21 & 2 & 2 & 2 & 2 & 2 & 10 \\
\hline 22 & 3 & 4 & 3 & 3 & 3 & 16 \\
\hline 23 & 2 & 2 & 2 & 2 & 2 & 10 \\
\hline 24 & 2 & 1 & 2 & 2 & 1 & 8 \\
\hline 25 & 3 & 3 & 2 & 3 & 3 & 14 \\
\hline 26 & 4 & 3 & 3 & 3 & 3 & 16 \\
\hline $\mathbf{x}$ & 3,12 & 2,9 & 2,73 & 2,8 & 2,8 & 14,3 \\
\hline
\end{tabular}

Note: The media or average of the control group regarding the post-test is 14, 3 over 25 .

Source: How to teach speaking-Scott Thornbury (2009)

Developed by: The authors

Creatividad, Diseño e Innovación 
ISSN: 2600-5859

wWw.concienciadigital.org

Vol. 3, $\mathrm{N}^{\circ} 1.1$, p. 408-426, febrero, 2020

Table 6

Post-test experimental group

\begin{tabular}{|c|c|c|c|c|c|c|}
\hline Student & Comprehension & Fluency & Grammar & Vocabulary & Pronunciation & Total \\
\hline 1 & 4 & 3 & 2 & 1 & 1 & 11 \\
\hline 2 & 4 & 3 & 3 & 3 & 4 & 17 \\
\hline 3 & 4 & 5 & 3 & 4 & 5 & 21 \\
\hline 4 & 4 & 3 & 2 & 3 & 2 & 14 \\
\hline 5 & 4 & 5 & 3 & 4 & 4 & 20 \\
\hline 6 & 5 & 5 & 5 & 5 & 5 & 25 \\
\hline 7 & 4 & 3 & 4 & 4 & 4 & 19 \\
\hline 8 & 5 & 5 & 3 & 4 & 5 & 22 \\
\hline 9 & 3 & 4 & 3 & 3 & 3 & 16 \\
\hline 10 & 5 & 5 & 5 & 5 & 5 & 25 \\
\hline 11 & 4 & 5 & 3 & 4 & 4 & 20 \\
\hline 12 & 5 & 5 & 3 & 4 & 5 & 22 \\
\hline 13 & 3 & 4 & 3 & 3 & 3 & 16 \\
\hline 14 & 5 & 5 & 5 & 5 & 5 & 25 \\
\hline 15 & 3 & 1 & 3 & 1 & 1 & 9 \\
\hline 16 & 4 & 3 & 4 & 4 & 4 & 19 \\
\hline 17 & 3 & 3 & 3 & 3 & 3 & 15 \\
\hline 18 & 4 & 2 & 3 & 3 & 2 & 14 \\
\hline 19 & 5 & 5 & 5 & 4 & 5 & 24 \\
\hline 20 & 4 & 5 & 3 & 4 & 5 & 21 \\
\hline 21 & 4 & 3 & 3 & 4 & 3 & 17 \\
\hline 22 & 3 & 2 & 3 & 3 & 2 & 13 \\
\hline 23 & 3 & 3 & 2 & 2 & 1 & 11 \\
\hline 24 & 5 & 5 & 4 & 4 & 5 & 23 \\
\hline 25 & 4 & 3 & 3 & 4 & 3 & 17 \\
\hline 26 & 5 & 5 & 5 & 5 & 5 & 25 \\
\hline $\mathbf{X}$ & 4,08 & $\mathbf{3 , 8 5}$ & 3,38 & $\mathbf{3 , 5 8}$ & 3,62 & 18,5 \\
\hline
\end{tabular}

Note: The media or average of the experimental group regarding the post-test is 18,50 over 25 .

Source: post- test experimental group

Developed by: The authors

Creatividad, Diseño e Innovación 


\section{Table 7}

Average comparison among all the tests

\begin{tabular}{ll}
\hline Average results & \\
\hline Pre-test control & 9,65 \\
Pre-test experimental & 9,62 \\
Post- test control & 14,3 \\
Post- test experimental & 18,5 \\
\hline
\end{tabular}

Source: speaking rubrics

Developed by: The authors

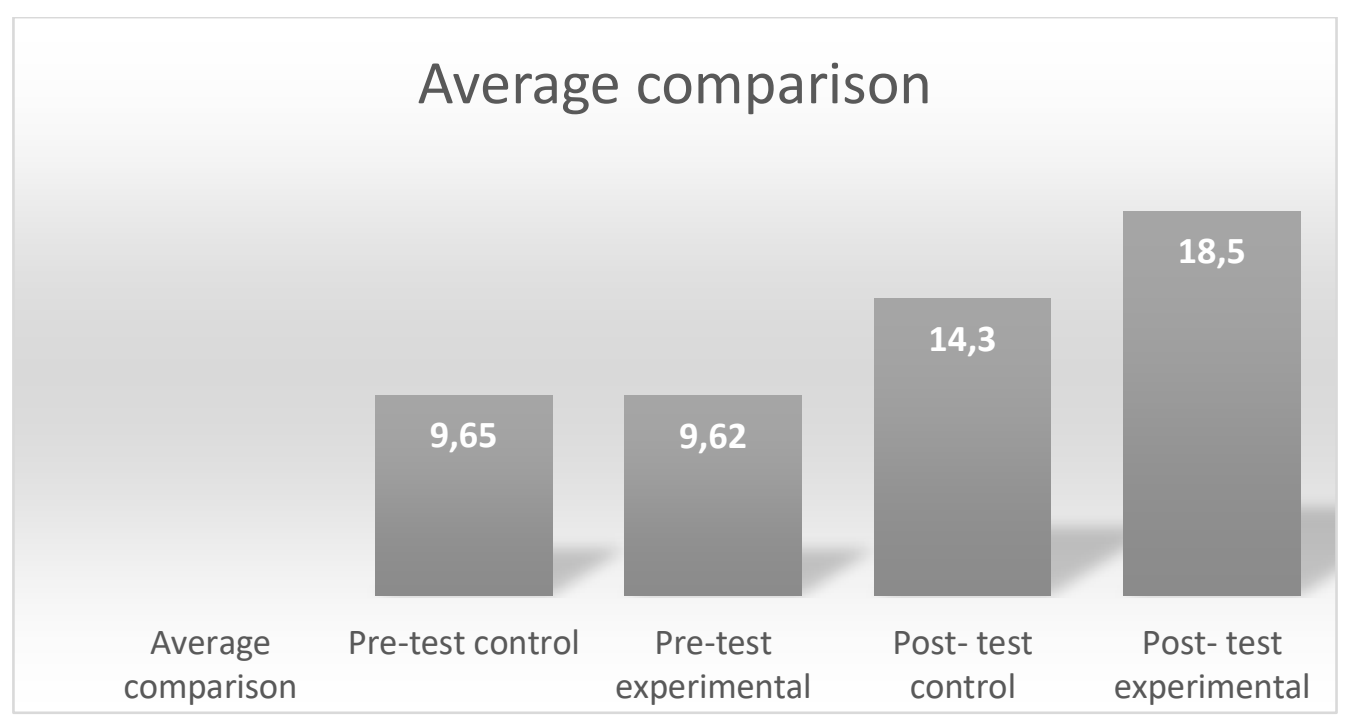

Figure 1. Average Comparison before and after the tests in both groups Developed by: The authors

The average comparison figure shows that the average of the control group in the pre-test is 9.65 and the average of the experimental group in this test is 9.62 . Consequently, both groups started with the same level of English knowledge.

After applying language games as a strategy to promote the speaking skill, the experimental group got an average of 18,5 , this is 4,5 points more than the average of the control group, which is 14,3 . This means that both groups had an increase in the post-test but the increase gotten in the experimental group was higher. Therefore, languages games enhanced students' speaking skill. 
ISSN: 2600-5859

WWW.concienciadigital.org

Vol. 3, $\mathrm{N}^{\circ} 1.1$, p. 408-426, febrero, 2020

\section{Conclusions}

- It has been demonstrated that language games enriched the speaking skill on English language learners who are beginner students at university. The data analysis showed that at the beginning of the English course students started with a basic level of their speaking skill, but after applying language games in classes their speaking grades improved, therefore, their speaking skill was empowered.

- Language games as go and stop, party talk, chain game, spelling contest, spelling survivor, what pic was it, hot chair, exit ticket, find your partner, memory game, how much you remember, bingo, Chinese whispers, charades, describe and draw and exit ticket enhanced the speaking skill on the learners who were part of the experimental group.

- Another finding is that language games as a strategy to teach speaking is useful. Language games are not only created for students to have fun but also to learn and to develop skills.

- Language games help students to have a low level of anxiety, keep them motivated to learn, make learners laugh and the most important fact is that students use the target language to communicate.

- Language games are an easy way to build students confidence when speaking English for they find them easy and engaging.

\section{Referencias bibliográficas}

Arikan, A., \& Yolagelddili, G. (2011). Effectiveness of Using Games in Teaching Grammar to Young Learners. Elementary Education Online, 10(1), 219-229. Retrieved from http://ilkogretim-online.org.tr/vol10say1/v10s1m18.pdf

Calle, Calle, Argudo, Moscoso, Smith, Cabrera, A. (2012). Los profesores de inglés y su práctica docente. Maskana, 1,2. Retrieved from https://repositorio.uta.edu.ec/bitstream/123456789/27519/1/Mena\%20Mayorga\%20Jazmi na\%20Ivonne.pdf 
ISSN: 2600-5859

Dewi, Kultsum, Armandi, R. (2016). Using Games in Improving Students' Speaking Skills. English Language Teaching, 63,64. Retrieved from https://repositorio.uta.edu.ec/bitstream/123456789/27519/1/Mena\%20Mayorga\%20Jazmina\% 20lvonne.pdf

Deesri, A. (2002). Games in the ESL and EFL class. The Internet TESL Journal, 8(9). Retrieved from http://iteslj.org/Techniques/Deesri-Games.html

Fisher, Schultz, A. (1998). Games for all reasons: Interacting in the Language Classroom. Brownstown: Longman Publishing Group. Retrieved from https://repositorio.uta.edu.ec/bitstream/123456789/27519/1/Mena\%20Mayorga\%20Jazmi na\%20Ivonne.pdf

Gaudart, H. (1999). Games as Teaching Tools for Teaching English to Speakers of other languages. Simulation and gaming, 290. Retrieved from https://repositorio.uta.edu.ec/bitstream/123456789/27519/1/Mena\%20Mayorga\%20Jazmi na\%20Ivonne.pdf

Hadfield, J. (1996). Intermediate Communication Games. Harlow: Logman. Retrieved from https://repositorio.uta.edu.ec/bitstream/123456789/27519/1/Mena\%20Mayorga\%20Jazmi na\%20Ivonne.pdf

Harmer, J. (2007). The practice of English Language Teaching. Cambridge: Longman.

Hernández, R., Fernández, C, \& Baptista, P. (2016). Metodología de la Investigación. México: McGraw Hill Education. Retrieved from https://repositorio.uta.edu.ec/bitstream/123456789/27519/1/Mena\%20Mayorga\%20Jazmina\% 20lvonne.pdf

Mahmoud, A., \& Tanni, Z. (2014). Using Games to Promote Students' Motivation towards Learning English. Journal for Educational and Psychological Research and studies, 1333. Retrieved from 
ISSN: 2600-5859

https://repositorio.uta.edu.ec/bitstream/123456789/27519/1/Mena\%20Mayorga\%20Jazmi na\%20Ivonne.pdf

Murphy, Sashi, M. (2017). Communication, Interactivity, and satisfaction in B2B relationships. Elsevier, 2.

Larsen-Freeman, D. (2004). Techniques and Principles in Language Teaching. New York:

Oxford

Sevy-Biloon, J. (2017). Different Reasons to play games in an English Language Class. Journal of Education and Training Studies, 89.

Thornbury, S. (2009). how to teach speaking. Harlow: Logman.

Tudor, I. (2001). Learner-centeredness as Language Education. United Kingdom: Cambridge University Press.

Ur, P. (1997). A Course in Language Teaching. New York: Cambridge University Press.

Urrutia León, W., \& Vega Cely, E. (2010). Encouraging Teenagers to Improve Speaking Skills through Games in a Colombian Public School. Profile Issues in Teachers' Professional Development, 16-17.

Yong, H. (2013, September 09). SlideShare. Retrieved from SlideShare: https://es.slideshare.net/HelenYong?utm_campaign=profiletracking\&utm_medium=sssite \&utm_source=ssslideview

Zaremba, A. (2006). Speaking professionally. Canada: Thompson South West. Retrieved from https://repositorio.uta.edu.ec/bitstream/123456789/27519/1/Mena\%20Mayorga\%20Jazmi na\%20Ivonne.pdf

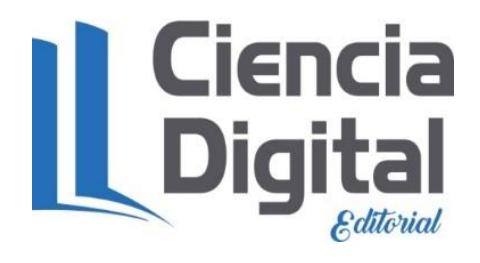


ISSN: 2600-5859

PARA CITAR EL ARTÍCULO INDEXADO

Mena Mayorga, J. I., Moreno Novillo, A. C., Mejía Calle, C. C., \& Silva Valencia, J. C. (2020). Juegos de lenguaje para mejorar la habilidad del habla en estudiantes de los primeros niveles del idioma inglés en la universidad. ConcienciaDigital, 3(1.1), 408-426. https://doi.org/10.33262/concienciadigital.v3i1.1.1157

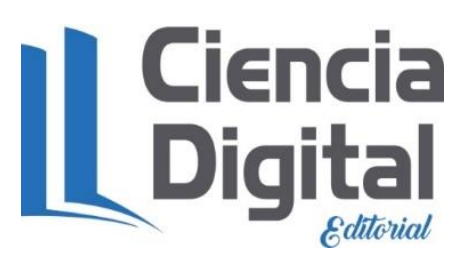

El artículo que se publica es de exclusiva responsabilidad de los autores y no necesariamente reflejan el pensamiento de la Revista Conciencia Digital.

El artículo queda en propiedad de la revista y, por tanto, su publicación parcial y/o total en otro medio tiene que ser autorizado por el director de la Revista Conciencia Digital.

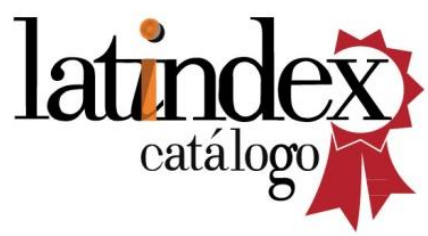

Conciencia

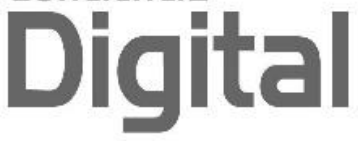

